\title{
Modulating Effect of 4,6,6-trimethylbicyclo [3.1.1] hept-3-ene on Antimicrobials Used to Combat Escherichia coli
}

\author{
Felipe Lemos Esteves do Amaral ${ }^{a}$, Ticiane Costa Farias ${ }^{a}$, Siluana Benvindo Ferreira ${ }^{b}$, \\ Savio Benvindo Ferreira ${ }^{c}$ \\ ${ }^{a}$ Graduate Student, Center for Teacher Training (CFP), Federal University of Campina Grande \\ (UFCG), Cajazeiras campus, Paraíba, Brazil \\ ${ }^{b}$ PhD in Veterinary Medicine, Agricultural Defense Agency of Piauí, Piauí, Brazil. \\ ${ }^{c}$ PhD Professor of the Academic Unit of Life Sciences, Center for Teacher Training (CFP), Federal \\ University of Campina Grande (UFCG), Cajazeiras campus, Paraíba, Brazil.
}

\section{Graphical Abstract}

Insert grafical abstract figure here

\section{Abstract.}

The growing number of resistant bacteria is considered a worldwide public health problem. In this context, several control initiatives have been proposed, such as the elaboration of medicines from vegetable raw material as an alternative to fight against microorganisms such as Escherichia coli, which is related to approximately $50 \%$ of hospital infections. $\alpha$-Pinene is found in the oils of many coniferous tree species and has antimicrobial activity against some microorganisms. The positive enantiomer of this compound (+) - $\alpha$ - pinene (+ AP), also called 4,6,6trimethylbicyclo [3.1.1] hept-3-ene, obtained from the company Sigma-Aldrich do Brasil Ltda. The solutions were dissolved in 1\% Tween 80 and 5\% DMSO and sterile distilled water was used to achieve desired concentrations. The tests were performed on the Escherichia coli strain ATTC 25922. To perform the modulation and adaptation tests, discs containing commercial antibiotics (ATM) were used. The modulating action of monoterpene was determined by the disc diffusion method. The antimicrobials Ceftazidime, Amoxicillin, Cefepime and Cefoxitin demonstrated synergism through association with phytoconstituent. For the remaining ATM, there was no statistically significant difference, and the effect of the association was classified as indifferent. It is concluded that 
phytoconstituent 4,6,6-trimethylbicyclo [3.1.1] hept-3-ene
could be used in combination with some drugs that
potentiate the destructive effect against E. coli ATCC
25922 , as long as it is submitted to tests that verify its
allergenic and toxic potential against humans. Similarly, the
association of this monoterpene with antibiotics that had
antagonistic or indifferent effects in this study should be
avoided.

\section{Introduction}

Currently, the class of antibiotics is at the top of the list of the most prescribed medications in the world, a fact that may be responsible for the development of bacterial resistance. Recent research shows that on average $50 \%$ of antimicrobials are not prescribed correctly by doctors, and the number of people who self-medicate without a professional indication is quite significant. Continuing these errors not only increases the selection of resistant strains, but also increases the costs of each patient and the effect of disease and death on a population (LIMA; BENJAMIM; SANTOS, 2017).

In theory, the practice of combining antimicrobial compounds would increase the chance of employing at least one effective agent to treat a given infection. In this case, if there were any resistance to one of the antimicrobials employed, but not to all, the microorganism would be destroyed by the agent (s) that maintained its activity in the scheme, with no resistance evolution (ZIMERMAN, 2010 ). In this context, the use of drugs of natural origin becomes an effective and economical alternative because they provide high chances of obtaining prototype molecules due to the diversity of their phytoconstituents with possibilities of increased antibacterial potential when associated with pathogen antibiotics (DE SOUZA ELLER et al., 2015).

In search of biological materials that interact in this sense, PEDROSA (2014) verified the association of three products, the phytoconstituent thymol, vancomycin and EDTA, which evaluated the sensitivity and the possibility of reducing the doses of the antibiotic cited against $E$. coli and may reduce the usual dose against this pathogen by up to sixteen times. In addition, other studies have shown that monoterpenes have detrimental effects on the bacterial cell membrane, showing themselves as alternatives to fighting pathogens such as E. coli, which is the subject of this study and is related to approximately $50 \%$ of hospital infections and $7090 \%$ of episodes of urinary tract infections (KORB et al., 2013).

Among these monoterpenes is $\alpha$-pinene, which has shown promise against bacterial biofilm formation and presented growth inhibition halos of E. coli strains. This fact demonstrates the possibility of using this phytoconstituent as an antimicrobial agent alone or in combination with other drugs (FARIAS et al., 2017). 
http://sciforum.net/conference/mol2net-05

Therefore, this study aims to evaluate the modulating effect of 4,6,6-trimethylbicyclo [3.1.1] hept-3-ene monoterpene, (+) - $\alpha$ - pinene, with antimicrobials used in clinical therapy to combat infections caused by Escherichia coli as a way to help fight resistant pathogens.

\section{Materials and Methods}

Phytoconstituent 4,6,6-trimethylbicyclo [3.1.1] hept-3-ene (+ AP), obtained from the company Sigma-Aldrich do Brasil Ltda. The solutions were dissolved in 1\% Tween 80 and 5\% DMSO and sterile distilled water was used to achieve desired concentrations. The tests were performed on the Escherichia coli strain ATTC 25922. The culture media used were Mueller-Hinton Agar (AMH), Mueller-Hinton Broth $(\mathrm{CMH})$ and BHI Broth (brain and heart infusion broth). For the modulation and adaptation tests, discs containing the commercial antibiotics (ATM) were used, and those acting on the bacterial cell wall were as follows: Cephalothin, Ceftazidime, Amoxicillin, Ampicillin, Cefepime, Cefoxitin, Meropenem and Cefuroxime. Prior to use, the media were solubilized in distilled water and autoclaved at $121^{\circ} \mathrm{C}$ for 15 minutes.

After the incubation period, the inoculum was prepared by making a direct suspension in saline of selected isolated colonies. The modulating action of monoterpene was determined by the disc diffusion method. After incubation of the plates at $35 \pm 2{ }^{\circ} \mathrm{C}$ for 24 hours, the diameter of the microbial growth inhibition halos was read. To investigate the effect of subinhibitory concentrations of 4,6,6trimethylbicyclo [3.1.1] hept-3-ene on the sensitivity profile of the tested strain, the adapted experimental protocol of Ultee et al. (2000) and McMahon et al (2007).

\section{Results and Discussion}

The study results were verified by comparing growth inhibition halos before and after association with the phytoconstituent to demonstrate whether there was a statistically significant change or synergism in this use, as can be seen in Figure 1. 


\section{Escherichia coli ATCC 25922}

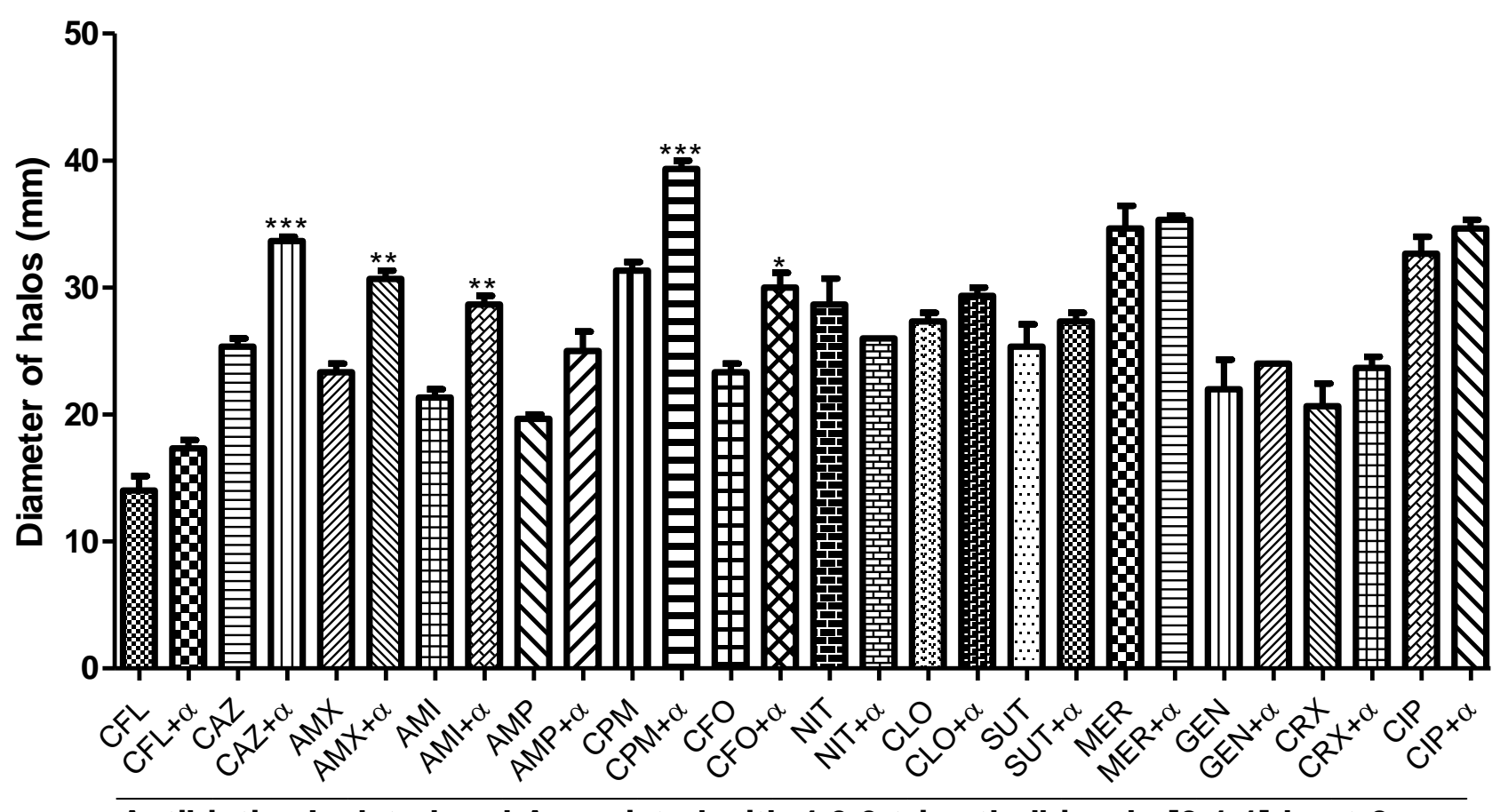

Antibiotics Isolated and Associated with 4,6,6-trimethylbicyclo [3.1.1] hept-3-ene

a-pineno - (+)-alfa-pineno CFL-Cefalotina, CAZ-Ceftazidime, AMX-Amoxicilina, AMI-Amicacina, AMPAmpicilina, CPM-Cefepime, CFO-Cefoxitina, NIT-Nitrofurantoína, CLO-Cloranfenicol, SUT-Sulfazotrim, MER-Meropenem, GEN-Gentamicina, CRX-Cefuroxime, CIP-Ciprofloxacina . Data were submitted to analysis of variance (One-Way ANOVA) and expressed as mean \pm m.s.e.

The following growth inhibitor halo diameters for antimicrobial isolated cell wall inhibitors and monoterpene inhibitors were as follows: $(+)$ - $\alpha$-pinene: $13.33 \mathrm{~mm}( \pm 0.58 \mathrm{~mm})$, Cephalothin: $14.00 \mathrm{~mm}$ ( $\pm 2.00 \mathrm{~mm}$ ), Ceftazidime: $25.33 \mathrm{~mm}( \pm 1.16 \mathrm{~mm})$, Amoxicillin: $23.33 \mathrm{~mm}( \pm 1.16 \mathrm{~mm})$, Amikacin: $21.33 \mathrm{~mm}( \pm 1.16 \mathrm{~mm})$, Ampicillin: $19.67 \mathrm{~mm}$ ( $\pm 0.58 \mathrm{~mm}$ ) Cefepime: $31.33 \mathrm{~mm}$ ( $\pm 1.16 \mathrm{~mm})$ ), Cefoxitin: $23.33 \mathrm{~mm}( \pm 1.16 \mathrm{~mm})$, Nitrofurantoin: $28.67 \mathrm{~mm}( \pm 3.51 \mathrm{~mm})$, Chloramphenicol: $27.33 \mathrm{~mm}$ $( \pm 1.16 \mathrm{~mm})$, Sulfazotrim: $25.33 \mathrm{~mm}( \pm 3.06 \mathrm{~mm})$, Meropenem: $34.67 \mathrm{~mm}( \pm 3,06 \mathrm{~mm})$, Gentamycin: $22.00 \mathrm{~mm}( \pm 4.00 \mathrm{~mm})$, Cefuroxime: $20.67 \mathrm{~mm}( \pm 3.06 \mathrm{~mm})$, Ciprofloxacin: 32, $67 \mathrm{~mm}( \pm 2.31 \mathrm{~mm})$.

Applying the classification proposed by Cleeland and Squires (1991) for the effect of interaction between substances, we can classify the effect of the association of phytoconstituent to the antimicrobials Ceftazidime, Amoxicillin, Cefepime and Cefoxitin as a synergistic effect. However, for the other ATMs, there was no statistically significant difference, and the effect of the association was classified as indifferent. Thus, if there was antagonism or indifference in the results for some drugs, the possibilities open for further studies on the resistance and adaptation mechanism of the strain used and how the synergistic associations were able to increase the potential toxic effect against the pathogen..

\section{Conclusions}


http://sciforum.net/conference/mol2net-05

Thus, it is concluded that phytoconstituent 4,6,6-trimethylbicyclo [3.1.1] hept-3-ene, having synergistic effects with some drugs tested in this work, can be used as an associated substance and potentiator against $E$. coli ATCC 25922, provided that it is submitted to tests to verify their allergenic potential against humans. Similarly, the association of this monoterpene with the antibiotics that had antagonistic or indifferent effects in this study should be avoided, not allowing the growth of resistant bacterial strains. Thus, opportunities are created for the reduction of morbidity and mortality associated with resistant microbes and for the reduction of toxicity related to certain commercially available drugs by reducing the doses used.

\section{References}

ASTRULLA, Tacuri; NADIA, Tow. Bacterias aisladas con mayor frecuencia y perfil de resistencia antibiótica en cultivos y antibiogramas de muestras procedentes de la unidad de cuidados intensivos del Hospital Regional Docente de Cajamarca 2017-2018. 2019

CLEELAND, R., SQUIRES, E. (1991) Evaluation of new antimicrobials in vitro and experimental animal infection In: Lorian, V. Antibiotics in laboratory medicine. 3. ed. Baltimore: Williams and Wilkiam, pp. 739-787.

CLINICAL LABORATORY STANDARDS INSTITUTE (CLSI). Padronização dos Testes de Sensibilidade a Antimicrobianos por Disco-difusão: Norma Aprovada - $8^{\mathrm{a}}$ ed. M2-8, vol. 23, n.1. Substitui a Norma M2-A7, v.20, n.1. 2005.

COUTINHO, Henrique DM et al. Avaliação comparativa da modulação de antibióticos, frente às cepas bacterianas de Escherichia coli, Staphylococcus aureus. Revista Ciencias de la Salud, v. 13, n. 3, p. 345-354, 2015.

DE ARAÚJO, ThaiseAnataly Maria et al. DIALOGANDO ACERCA DA FORMAÇÃO EM NUTRIÇÃO: UMA REVISÃO CRÍTICA DAS EVIDÊNCIAS. Ambiente: osdesafios da interdisciplinaridadenosciclos da vidahumana, p. 118.

DE SOUZA ELLER, Sarah Carobini Werner et al. Avaliação antimicrobiana de extratos vegetais e possível interação farmacológica in vitro. Journal of Basic and Applied Pharmaceutical Sciencies, v. 36, n. 1, 2015.

FARIAS, Ticiane Costa et al. Screening antibacteriano do (+)- $\alpha-$ pinenofrente a cepasbacterianas gram negativas. In: II Congresso Brasileiro de Ciências da Saúde. 2017.

KORB, Arnildo et al. Perfil de resistência da bactéria Escherichia coli eminfecções do tratourinárioempacientesambulatoriais. Rev Biol Ciênc Terra, v. 13, p. 72-79, 2013.

LIMA, Camila Correa; BENJAMIM, Sandra Cristina Calixto; SANTOS, Rosana Francisco Siqueira dos. Mecanismo de resistência bacteriana frente aos fármacos: uma revisão. CuidArte, Enferm, v. 11, n. 1, p. 105-113, 2017.

MCMAHON, M. S. et al. Habituation to sub-lethal concentrations of tea tree oil (Melaleuca alternifolia) is associated with reduced susceptibility to antibiotics in human pathogens. J Antimicrob Chemother, v. 59, p. 125-127, 2007. 
OLIVEIRA, Adriana Cristina de; SILVA, Rafael Souza da. Desafios do cuidaremsaúdefrente à resistênciabacteriana: uma revisão. RevistaEletrônica de Enfermagem, v. 10, n. 1, 2008.

PEDROSA, Zilmara Vieira. Atividade do Coriandrum sativum l. sobre cepas de Escherichia coli produtoras de $\boldsymbol{\beta}$-lactamases de espectro estendido. Tese (Tese em Produtos Naturais e Sintéticos Bioativos) - UFPB. João Pessoa, 2014.

RODRIGUES, Laís Azevedo et al. Elaboração de um fitoterápicoantibiótico a partir da casca de Anadenantheramacrocarpa. Revista científica da Faminas, v. 10, n. 3, 2016.

ZIMERMAN, Ricardo Ariel. Uso indiscriminado de antimicrobianos e resistência microbiana. Uso racional de medicamentos: Temas selecionados. Ministério da saúde, n. 3, 2010. 